DOI: http://dx.doi.org/10.21123/bsj.2016.13.1.0133

\title{
Isolation and Purification of a Cyclooxygenase-2 from the Blood of a Patient Suffering from Rheumatoid Arthritis and Studying the Effect of Natural Products of the Soapwort on the Activity of Purified Enzyme
}

\author{
Mohammed B. Al-Sadoun* \\ Osama M. AL-Sabaawy** \\ *Department of Chemistry, College of Science, University of Mosul, Mosul - IRAQ \\ **Department of Biochemistry, Nineveh College of Medicine, University of Nineveh, \\ Mosul - IRAQ \\ E-mail: Osama8293@yahoo.com
}

Received 25, January, 2015

Accepted 26, April, 2015

(1) ()

EY NO No This work is licensed under a Creative Commons Attribution-NonCommercial-

NoDerivatives 4.0 International Licens

Abstract:

In this paper to isolate and study the properties of the cyclooxygenase-2 (EC: 1.14.99.1) enzyme in the blood of a patient suffering from rheumatoid arthritis and study the effect of natural products of the Soapwort on the activity of purified enzyme. The study involves taking $30 \mathrm{ml}$ of blood from an adult woman 40 years old, who suffers from rheumatoid arthritis disease for 13 years. Serum is separated and subjected to a series of purification processes including: precipitation by ammonium sulfate, filtration by centrifugation radiator, dialysis in presence of ammonium bicarbonate, separation using the technology of ion exchange, lipholization and then estimating approximate molecular weight of the enzyme using gel filtration technique and sodium dodecyl sulfate (SDS)-page polyacrylamide gel electrophoresis. The study also includes isolating the natural products of Soapwort plant and study the effect of isolated natural products on the activity of the purified enzyme. The result of the study indicates that cycloxygenase- 2 has an approximate molecular weight of 71.5 $\mathrm{kDa}$ and that the extracted oil of the Soapwort has a negative impact on the activity of the enzyme $(\mathrm{r}=-0.824 ; P=0.006)$, while flavonoids and Saponin have no such impact ( $\mathrm{r}=-0.565 ; P=0.113 ; \mathrm{r}=-0.634 ; P=0.067$ respectively).

Key words: Cyclooxygenase-2, Rheumatoid Arthritis, Purification. Soapwort.

\section{Introduction:}

Cyclooxygenase (COX, also called prostaglandin $\mathrm{H}$ synthase or PGHS), (EC: 1.14.99.1), is a key enzyme in the synthesis of prostanoids $[1,2]$. This enzyme has two activities, a cyclooxygenase and peroxidase thereby responsible for catalyzing the conversion of arachidonic acid into prostaglandin G2, which are further peroxidised to prostaglandins $\mathrm{H} 2$, the precursor of molecules, such as prostaglandins, prostacyclin, and thromboxanes $[3,4]$. COX exists in two isoforms, COX-1 and COX-2. COX-1 is known to be a constitutive enzyme that is responsible for the normal physiological functions including maintenance of the integrity of the gastric mucosa and regulation of renal blood flow. By contrast, the 
expression of COX-2 can be induced by cytokines/growth factors or inflammatory stimuli and has been associated with the elevated production of prostaglandins observed during inflammation, pain, and pyretic responses [5].

With rheumatoid arthritis (RA), there occurs a local cellular proliferation of synoviocytes results in a marked expansion of the synovium called pannus, which in turn, invades and destroys articular structure. Inflammatory mediators, including tumor necrosis factor (TNF) and interleukin (IL-1), release from the inflammatory cells in response to various stimuli activate fibroblast-like synovial cells. The important feature of synovial cells is that the cells stimulate COX-2 expression [6], for this reason, the blood sample that applies in the current study is selected from a patient with rheumatoid arthritis because in the case of rheumatoid arthritis the inflammation gets out of control and the immunity system becomes more active and thus increases the concentration of the factors that induce the secretion of the COX-2 enzyme such as lipopolysaccharides [7] cytokines [8], tumor necrosis factor (TNF) [9]. Soapwort is a genus of flowering plants from the south-west Asia on the borders of Turkey and Iraq [10]. Soapwort has many common names, in Arabic is called 'erq al halaweh, but the scientific name is Saponaria, which derives from the Latin saponis ("soap") and -aria ("pertaining to sap"). The most familiar species might be common Saponaria officinalis used to make soap_[11].

Roots of Soapwort are exploited commercially for a variety of purposes including medicines, detergents, adjuvants and cosmetics [12]. In the medical, Soapwort has an anti-alopecia activity [13], an antimicrobial activity while its role as an anti-inflammatory is not studied till now. In rheumatoid arthritis, there occurs a failure of acute inflammation to resolve may predispose to: autoimmunity, chronic dysplastic inflammation, excessive tissue damage and occurs dramatic increase of COX2 expression [14], and because COX-2 is one of the most important enzymes that is responsible for inflammation, the current study aims to purify COX-2 from a blood of a patient with rheumatoid arthritis and then study the effect of Soapwort natural products on the activity of purified enzyme.

\section{Materials and Methods:}

\section{A- Isolation and Purification of the COX-2 Enzyme}

The blood sample size of $30 \mathrm{ml}$ is taken from a 40 -year- old woman suffering from rheumatoid arthritis disease for 13 years, had visited IbnSenna hospital in Mosul on the 10 the February 2014. Factors affecting COX2 activity are excluded from the history. The blood is allowed at $37^{\circ} \mathrm{C}$ and then centrifuged at $3000 \mathrm{rpm}(900$ $x g$ ) for $15 \mathrm{~min}$. The serum is separated and stored at $-10^{\circ} \mathrm{C}$ until its analysis [15]. The analysis includes a series of purification steps including: salting out, which is conducted at $4{ }^{\circ} \mathrm{C}$ by gradually adding of ammonium sulfate to the serum $(0-50 \%)$ with a constant stirring by the magnetic stirrer until reaching the saturation point, then the separation is done by the centrifugation radiator to move to the next step [16]. Dialysis, the other process, is conducted at $4^{\circ} \mathrm{C}$ after dissolving the precipitate yielding the least possible amount of distilled water and then it is transferred into a special plastic bag for dialysis. The plastic bag is transferred into a jar filled with ammonium bicarbonate $(0.1 \mathrm{M})$, the plastic bag is completely covered with ammonium bicarbonate to avoid any shrinkage and subsequently is losing its permeability. 
The external ammonium bicarbonate is changed every four hours during the dialysis process until the enzyme solution volume inside the plastic bag reaches a constant one. The final size of the sample, the amount of protein and the effectiveness of the enzyme are all estimated after dialysis [17]. IonExchange Chromatography, the negatively charged COX-2 enzyme is separated by using a positively charged diethylaminoethyl-cellulose (DEAEcellulose) column. The enzyme is bound to such a column and is eluted from it by using a graded concentration (from $0.1 \mathrm{M}$ to $0.3 \mathrm{M}$ ) of buffer solution (tris hydroxymethyl aminomethane). Parts separated from the ion exchange column are collected in a number of laboratory tubes at a rate of $2.5 \mathrm{ml} / 5$ minutes. The protein is followed up by tracking the absorbance at $280 \mathrm{~nm}$, while the follow-up of COX-2 enzyme, that we are looking for, occurs by measuring the activity in all the separated parts [18, 19]. Lyophilization, the solution that contain a protein peak resulting from ion exchange process is frozen in a plastic beaker at $-20{ }^{\circ} \mathrm{C}$ and then put in Lyophilizer [20]. Gel filtration technique is used to estimate the approximate molecular weight of the enzyme, the elution is carried out at a flow rate $5 \mathrm{ml} / 7 \mathrm{~min}$ whereas the fractions are examined for the COX-2 activity [21]. Number of compounds (standards), known as molecular weight (204 - 2000000 Dalton), are passing through the separation column with the dimensions $(2.0 \mathrm{~cm} \mathrm{X} 100$ $\mathrm{cm})$ filled by the gel type Sephadex G100 to calculate the elution volume for each compound, and then attended standard curve by drawing the logarithm molecular weight against elution volume. Approximate molecular weight of COX-2 enzyme is found from this curve. SDS-PAGE poly acrylamide gel electrophoresis is the most widely used method for qualitatively analyzing protein mixtures [22]. Laemmli method is used [23] for monitoring the enzyme purification, and because the method is based on separating the proteins according to size, the method is also used to determine the relative molecular weight of enzyme. To determine the molecular weight of COX-2, the relative distance of the standard proteins are determined and a graph of $\log$ molecular weight vs. distance is plotted. The distance of the COX-2 is then is determined and the $\log$ molecular weight (and hence molecular weight) is determined from this graph.

\section{B- Estimation of the COX-2 Activity}

The activity of the COX-2 enzyme is estimated by an assay for the peroxidase activity based on a colorimetric procedure [24]. This method depends on measuring the enzyme-catalyzed oxidation of tetramethyl phenylenediamine (TMPD) by hydrogen peroxide. The blue reaction measured at $610 \mathrm{~nm}$. One unit of activity is defined as the amount of enzyme required to convert $1 \mu \mathrm{mol}$ of hydrogen peroxide to the product under assay condition.

\section{C- Estimation of the Total Protein}

The amount of total protein is determined by the modified Lowry's method [25].

\section{D- Extraction and Identification of the Natural Products of the Soapwort}

About 200g of the roots of the Soapworts (purchased from apothecaries market of Mosul City) are milled in a blender, the resulting powder is packaged in cloth bag and then the cloth bag is transferred to a Soxhlet instrument. $250 \mathrm{ml}$ of the extracted solvent Petroleum Ether 60$80^{\circ} \mathrm{C}$ is added to the round of 
instrument and is used to extract oil at $60^{\circ} \mathrm{C}$ according to method of Zekovie et al, [26]. Volatile oils have been detected by moisturizing its filter paper and then exposing the paper to ultraviolet light where the appearance of the color pink indicates the presence of the volatile oils in the extract [27].

To make sure of the presence of fatty acids in the extracted oil, $0.5 \mathrm{ml}$ of the oil is placed in a clean tube, then $2 \mathrm{ml}$ of chloroform is added and the content is mixed well then concentrated using the nitrogen gas [28]. One spot of the concentrated oil is put on the ALPHA FT-IR, Atrdiamood Bruker optic (Germany) Spectrometer located in College of Agriculture - Central Laboratory in Mosul University. The result shows the presence of sites belonging to the absorption of fatty acids, but it is difficult to distinguish the types of each fatty acids in the presence of overlapping beams, for this reason, thin layer chromatography technique (TLC) is used to disperse the fatty acids firstly and then diagnose each fatty acid.

One spot of concentrated oil is put on the thin layer silica gel $(20 \times 20)$ $\mathrm{cm}$. The spot is left to ascend into silica gel by using a mobile phase which consists of a mixture of hexane: ether: formic acid (80:20:2, V/V/V), then the plates are dried at room temperature and sprayed by dye (2, 7 dichlorofluorescein) that appear spots in green-yellow color after the exposure to ultraviolet rays [28].

Flavonoids are extracted from the remaining (pulp) of Soapwort (powder that lost oil) as shown in Figure1. The powder is packaged in cloth bag and then cloth bag is transferred to Soxhlet instrument. 250 $\mathrm{ml}$ of pure solvent (Methanol) is added to the round of instrument and used to extract flavonoids according to method of Kato et al, [29]. Flavonoids have been detected by mixing equal volumes of solution A (consisting of 5 $\mathrm{ml}$ of extract flavonoids) and solution B (consisting $10 \mathrm{ml}$ of ethanol, $50 \%$ $+10 \mathrm{ml}$ of potassium hydroxide $50 \%$ ), the appearance of yellow color indicates the presence of flavonoids [30].

Saponin is extracted from the remaining (pulp) of Soapwort (powder that lost both the oil and flavonoids). The powder is packaged in cloth bag and then the cloth bag is transferred to Soxhlet instrument. $250 \mathrm{ml}$ of extracting solvent $\left(\mathrm{H}_{2} \mathrm{O}\right)$ is added to the round of instrument and used to extract Saponin. The solution that contains Saponin resulting from extraction process is frozen in a plastic beaker at $-20{ }^{\circ} \mathrm{C}$ and then put in Lyophilizer [31]. Saponin has been detected by adding $3 \mathrm{ml}$ of mercuric chloride to $5 \mathrm{ml}$ of extract Saponin where the appearance of white color indicates the presence of Saponin [32].

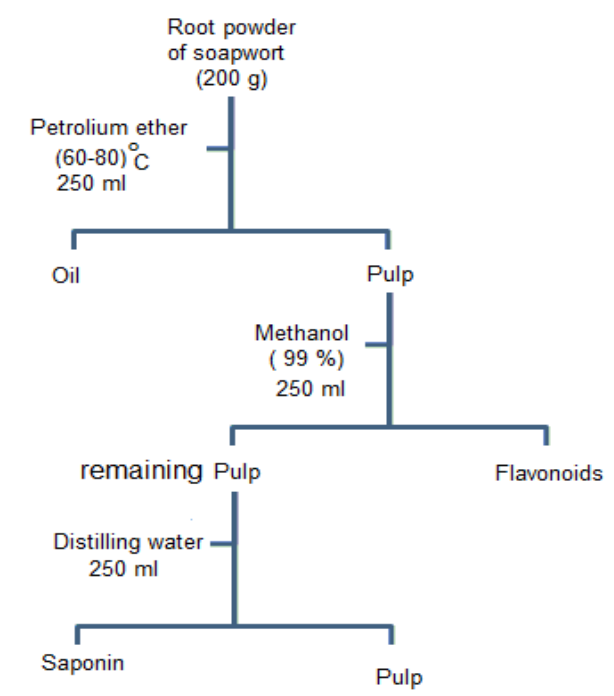

Fig 1. : The Stages of Natural Products Extraction from Soapwort Roots.

\section{E- Studying the Effect of Natural Products and some Drugs on the Activity of COX-2:}

The effect of natural products of the Soapwort and some antiinflammatory drugs such Aspirin, Ibuprofen, Indometacine on the 
activity of COX-2 is studied after attending these natural products and drugs in concentrations ranging from $(0-408 \quad \mu \mathrm{g} / \mathrm{ml}), \quad(3-12 \quad \mathrm{mM})$ respectively. It is used in the enzymatic reaction as soluble sample then determined the activity of the enzyme at different concentrations of each material.

Samples of soluble drugs (3-12 $\mathrm{mM}$ ) are prepared freshly from a 100 mM stock. To prepare $100 \mathrm{mM}$ stock solutions, each drug is first solubilized in ethanol, followed by dilution with distilled water [33].

Samples of soluble natural products $(0-408 \mu \mathrm{g} / \mathrm{ml})$ are prepared freshly from a $1000 \mu \mathrm{g} / \mathrm{ml}$ stock. To prepare $1000 \mu \mathrm{g} / \mathrm{ml}$ stock oil, oil is first solubilized in chloroform, followed by dilution with distilled water. To prepare $1000 \mu \mathrm{g} / \mathrm{ml}$ stock flavonoid. Flavonoid is first solubilized in ethanol, followed by dilution with distilled water. To prepare $1000 \mu \mathrm{g} / \mathrm{ml}$ stock saponin. Saponin was solubilized in distilled water [31].

\section{Statistical Analysis}

Data are statistically analyzed by using Minitab statistical software (version 13). Correlations are determined by Pearson's test. $\mathrm{P}$ values $<0.05$ are considered statistically significant.

\section{Results:}

\section{A- Results of the Purified Enzyme}

The purification of the COX-2 enzyme includes a series of steps summarized in Table 1, where we try to purify the COX-2 enzyme by ion exchange technique. The draw which represent absorbance, at a wavelength of $280 \mathrm{~nm}$, against elution volume given two peaks $\mathrm{A}$ and $\mathrm{B}$. When we trace the COX-2 enzyme through our measuring the activity in both peaks (A and $\mathrm{B})$, the results show that the highest activity of COX-2 is located in peak $\mathrm{C}$, which is part of the peak $\mathrm{A}$ as shown in Figure 2.

Table 1: Purification Steps of COX-2 Enzyme.

\begin{tabular}{|c|c|c|c|c|c|c|c|c|c|}
\hline \multicolumn{2}{|c|}{$\begin{array}{l}\text { purification } \\
\text { steps }\end{array}$} & $\begin{array}{l}\text { Volume } \\
(\mathrm{ml})\end{array}$ & $\begin{array}{c}\text { Protein } \\
\text { Concentration } \\
(\mathrm{mg} / \mathrm{ml})\end{array}$ & $\begin{array}{c}\text { Total } \\
\text { Protein } \\
\text { (mg) }\end{array}$ & $\begin{array}{l}\text { Enzyme } \\
\text { activity } \\
\text { (U/ml) } \\
\times 10-^{3} \\
\end{array}$ & $\begin{array}{c}\text { Total } \\
\text { activity } \\
(\mathrm{U})^{*} \\
\mathrm{x} 10^{-3} \\
\end{array}$ & $\begin{array}{c}\text { Specific } \\
\text { activity } \\
\text { (U/mg) } \\
\times 10-^{3} \\
\end{array}$ & Fold & $\begin{array}{c}\text { Yield } \\
\%\end{array}$ \\
\hline \multicolumn{2}{|l|}{ Serum } & 15 & 83.67 & 1255 & 5.16 & 77.4 & 0.061 & 1 & 100 \\
\hline \multicolumn{2}{|c|}{$\begin{array}{c}\text { Precipitation by ammonium } \\
\text { sulphate }(50 \%)\end{array}$} & 12.25 & 68.57 & 840 & 4.91 & 60.14 & 0.071 & 1.16 & 66.93 \\
\hline \multicolumn{2}{|c|}{ Dialysis } & 12.75 & 52.2 & 665.5 & 4.58 & 58.4 & 0.087 & 1.42 & 53.03 \\
\hline $\begin{array}{l}\text { Ion exchange } \\
\text { chromatography }\end{array}$ & $\begin{array}{l}\text { Peak } \\
\text { (C) }\end{array}$ & $36^{\#}$ & 1.38 & 49.68 & 1.58 & 56.88 & 1.14 & 18.68 & 3.95 \\
\hline
\end{tabular}

*U: One unit of activity is defined as the amount of enzyme required to convert $1 \mu \mathrm{mol}$ of hydrogen peroxide to the product under assay condition.

\#: Volume of enzymatic solution in peak (C) after lyophilization. 


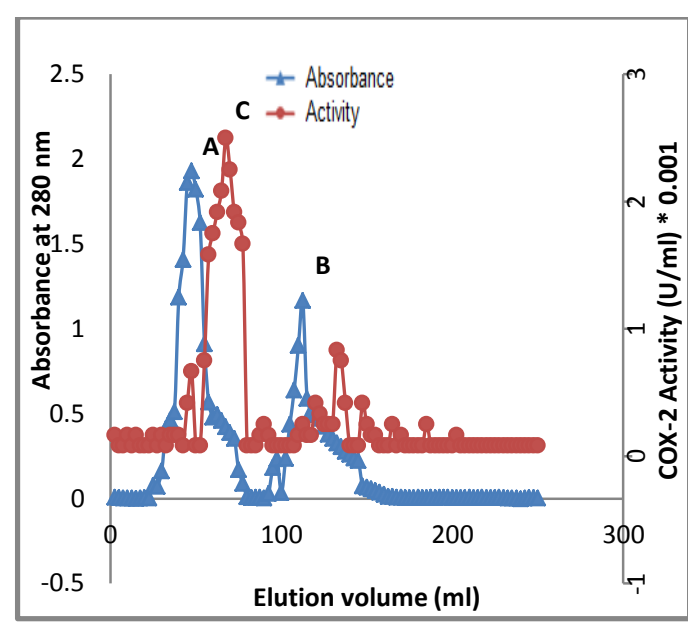

Fig. 2: The Peaks of Protein and COX-2 Enzyme Outputting from the Ion Exchange Chromatography Column $(2.5 \times 40) \mathrm{cm}$.

Estimating the Approximate Molecular Weight of the COX-2

1- By Gel Filtration Technique:

As shown in Figure 3, the elution volume of COX-2 solution, collected from gel filtration separation column, is $110 \mathrm{ml}$ and this correspond to a molecular weight of $71.5 \mathrm{kDa}$ when using the standard curve shown in Figure 4.

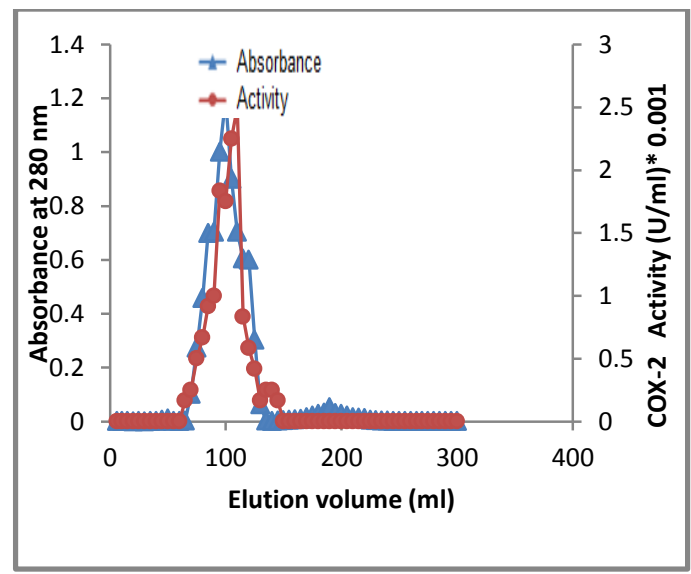

Fig. 3: The Peaks of Absorbance and Activity of COX-2 Enzyme Outputting from Gel Filtration Column ( $2 \times 100)$ cm.

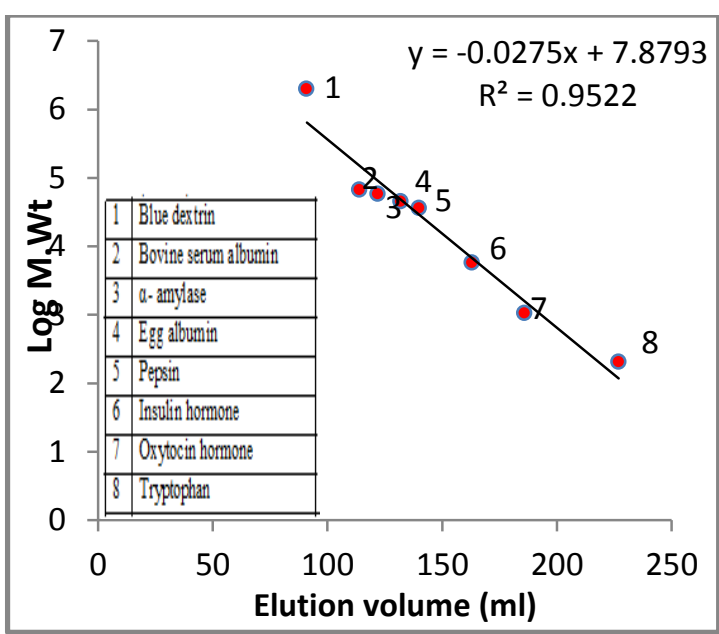

Fig. 4: Calibration Curve Used to Determine the Approximate Molecular Weight of COX-2 Using Gel Filtration Technique.

\section{2- By SDS-PAGE Gel}

Electrophoresis

As shown in Figure (6), the pure enzyme obtained shows a single band when analyzed by acrylamide electrophoresis in the presence of $0.1 \%$ sodium dodecyl sulfate. The relative distance of the COX-2 is $(4.85 \mathrm{~cm})$ and it is clear that the enzyme has a molecular weight equal to $(71.6 \mathrm{kDa})$ when using the standard curve shown in Figure 5.

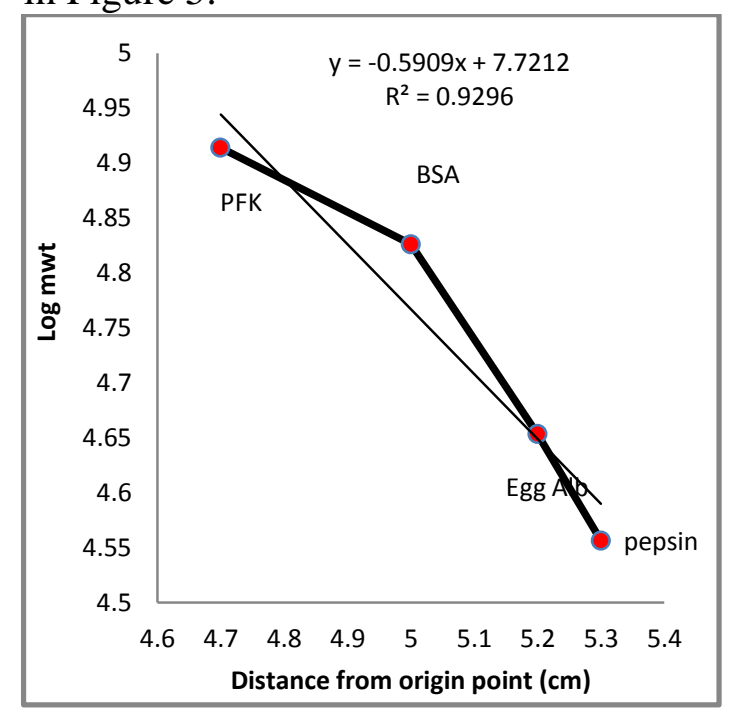

Fig. 5: Calibration Curve Used to Determine the Approximate Molecular Weight of COX-2 Using SDS-Page Polyacrylamide Electrophoresis. 


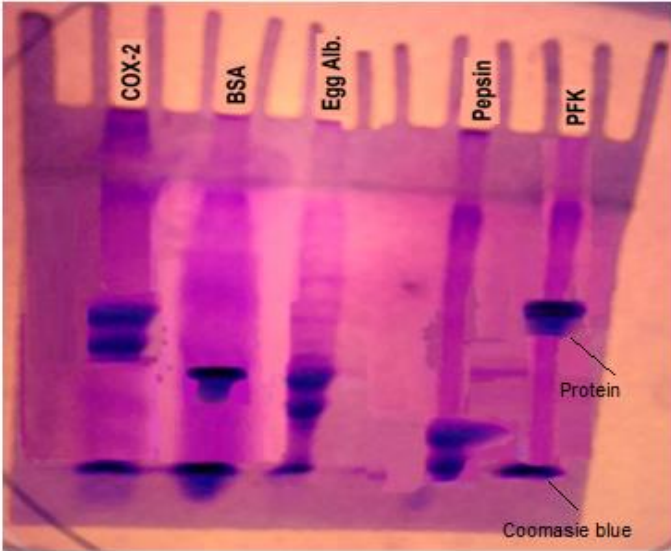

Fig.6: SDS-PAGE Analysis Bands of the Purified COX-2 and the Standard Proteins

\section{B- Extraction and Identification of Natural Products of the Soapwort.}

The result of the chemical tests shows the presence of the volatile oils, flavonoids and Saponins in the roots powder of Soapwort. IR technique is also applied to identify the presence of fatty acids in volatile oil.

The result of FT-IR Spectrometer shows the presence of sites belonging to the absorption of fatty acids, as shown in Figure 7 and Table 2, but it is difficult to distinguish these fatty acids in the presence of overlapping beams. For this reason, TLC technique is used to disperse these fatty acids from the other compounds in oil extracted and then identifying each one of the fatty acid by comparing its $\mathrm{Rf}$ value with the with the Rf value of the corresponding standard.

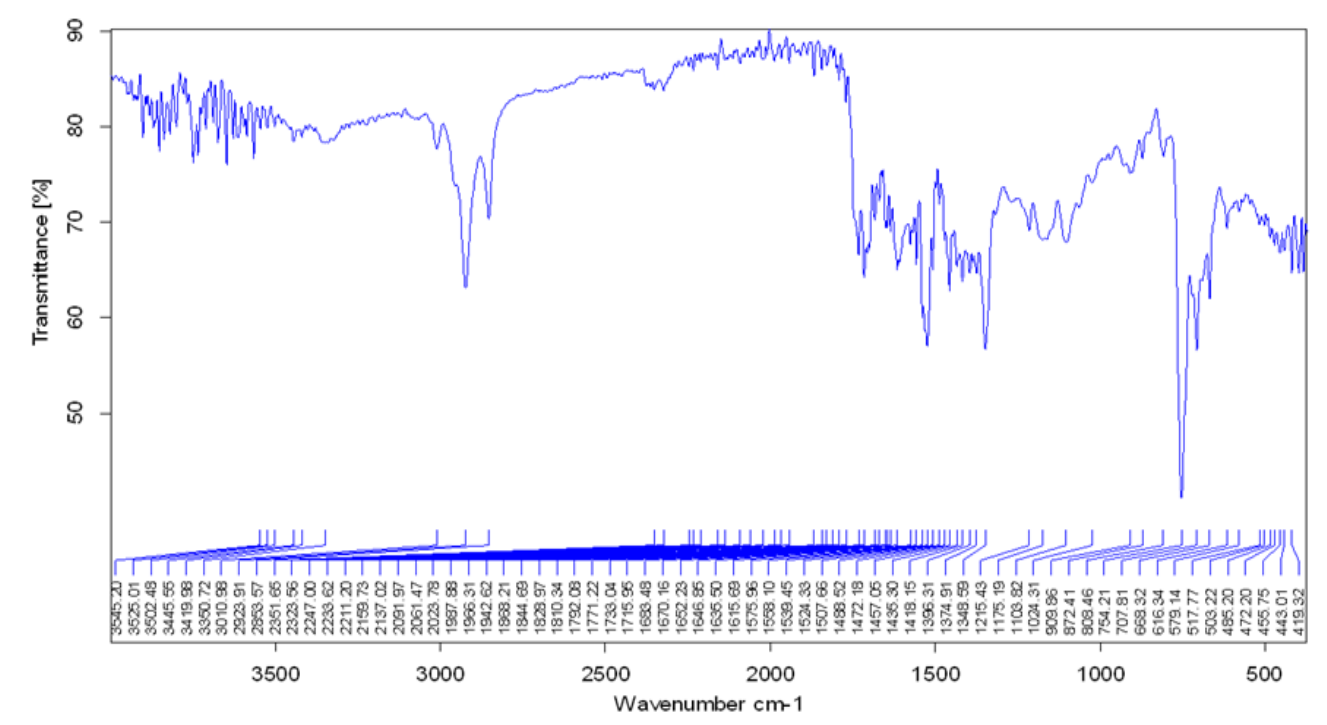

Fig 7: Infrared Spectrum for the Oil Extracted from the Soapwort Plant.

Table 2: Infrared sites belonging to the absorption of fatty acids in extracted oil

\begin{tabular}{|c|c|c|c|c|c|c|}
\hline OH-streach & $\begin{array}{c}\text { COO- } \\
\text { carboxylic } \\
\text { acid }\end{array}$ & $\begin{array}{c}\text { OH- } \\
\text { carboxylic } \\
\text { acid }\end{array}$ & $\begin{array}{c}\text { CH=C-H } \\
\text { olivine } \\
\text { hydrogen }\end{array}$ & $\begin{array}{c}\text { CH3-CH-H } \\
\text { Aliphatic } \\
\text { hydrogen(s)* }\end{array}$ & $\begin{array}{c}\text { CH3-CH-H } \\
\text { Aliphatic } \\
\text { hydrogen(a)* }\end{array}$ & $\begin{array}{c}\text {-CH=CH- } \\
\text { Aliphatic } \\
\text { unsaturated } \\
\text { bound }\end{array}$ \\
\hline $3350 \mathrm{~cm}^{-1}$ & $\begin{array}{l}1716 \\
\mathrm{~cm}^{-1}\end{array}$ & $\begin{array}{c}1457 \\
\mathrm{~cm}^{-1}\end{array}$ & $\begin{array}{c}3011 \\
\mathrm{~cm}^{-1}\end{array}$ & $\begin{array}{c}2853 \\
\mathrm{~cm}^{-1}\end{array}$ & $\begin{array}{c}2923 \\
\mathrm{~cm}^{-1}\end{array}$ & $\begin{array}{c}1636-1615 \\
\mathrm{~cm}^{-1}\end{array}$ \\
\hline
\end{tabular}

The result of TLC shows four different spots and their Rf values are recorded in Table 3. Comparing these $\mathrm{Rf}$ values with the $\mathrm{Rf}$ values of the standard fatty acids have been found: spot 1 with $\mathrm{Rf}$ value 0.228 could not be identified, spot 2 with $\mathrm{Rf}$ value 0.6 is close to the standard $\mathrm{Rf}$ value of Palmetic acid,spot 3 with $\mathrm{Rf}$ value 0.8 is close to the standard $\mathrm{Rf}$ value of Linoleic, spot 4 with $\mathrm{Rf}$ value 0.914 close to the standard $\mathrm{Rf}$ value of Linolenic. 
Table 3: Comparison of the Rf Values of Fatty Acids Spots with the Rf Values of the Fatty Acids Standards.

\begin{tabular}{|c|c|c|c|c|}
\hline $\begin{array}{c}\text { Free fatty } \\
\text { acids }\end{array}$ & Rf values & $\begin{array}{c}\text { Spots of Fatty } \\
\text { acid }\end{array}$ & $\begin{array}{c}\text { Rf -values of TLC } \\
\text { separation }\end{array}$ & Inference \\
\hline caproic & 0.95 & 1 & 0.228 & Could not be identified \\
\hline palmetic & 0.6 & 2 & 0.6 & palmetic acid \\
\hline stearic & 0.51 & - & - & - \\
\hline oleic & 0.7 & - & - & - \\
\hline linoleic & 0.78 & 3 & 0.8 & linoleic acid \\
\hline linolenic & 0.88 & 4 & 0.914 & linolenic \\
\hline
\end{tabular}

C- The Effect of Natural Products of the Soapwort on the Activity of the Purified COX-2.

The result of study shows that the extracted oil has a negative impact on the activity of COX-2 enzyme ( $\mathrm{r}=$ $0.824 ; P=0.006)$ as shown in Figure 8 a. Flavonoids and Saponin natural products have no such correlation $(\mathrm{r}=$ $0.565 ; P=0.113 ; \mathrm{r}=-0.634 ; P=0.067)$ respectively as shown in Figure $8 b$ and Figure $8 \mathrm{c}$ respectively.

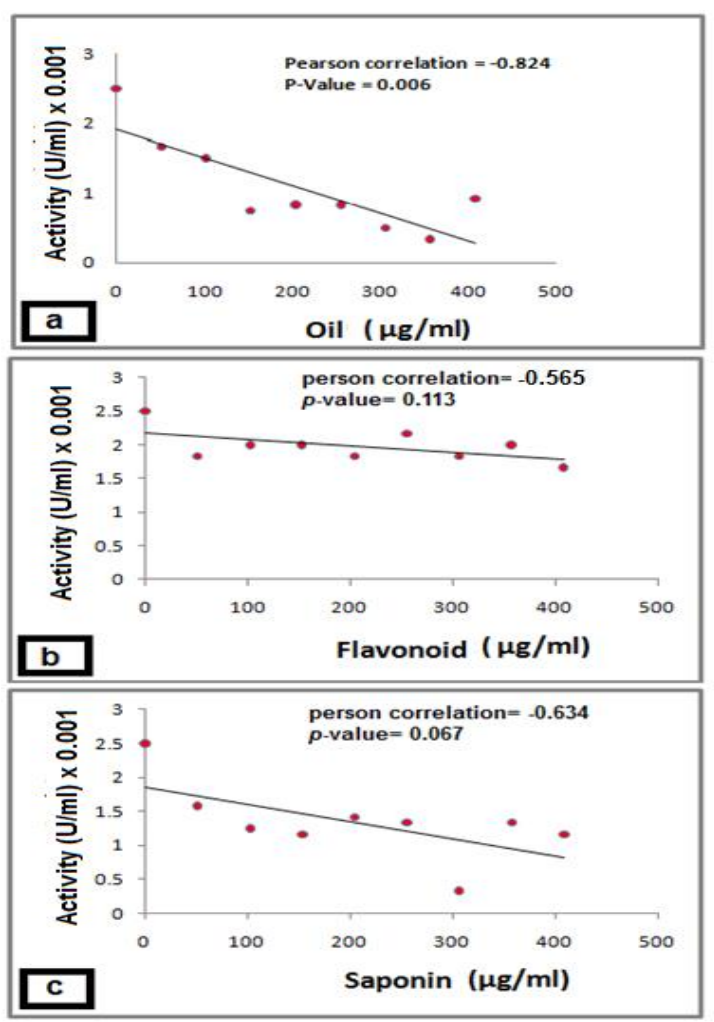

Fig. 8: The Effect of Soapwort's Natural Products on the Activity of COX-2 Enzyme
D- The Inhibition Percentage of the Oil of the Soapwort and some AntiInflammatory Drugs in the Activity of Purified COX-2 Enzyme.

The inhibition effect of some antiinflammatory drugs such Aspirin, Ibuprofen, Indometacine and Soapwort's oil on the purified COX-2 is studied by preparing different concentrations of each drug and using it in the enzymatic reaction. The result of the study shows that each drug exhibits different inhibitory percentage on the activity of COX-2 as shown in the Table 4.

Table 4: The Inhibition Percentage of the Soapwort's Oil and some AntiInflammatory Drugs in the Activity of the Purified COX-2.

\begin{tabular}{|c|c|c|c|}
\hline Drugs & Concentration & $\begin{array}{l}\text { Activity } \\
\mathrm{U} / \mathrm{ml}_{3}^{*} 10^{-}\end{array}$ & $\begin{array}{l}\text { Inhibition } \\
\text { percentage }\end{array}$ \\
\hline \multirow{4}{*}{ Aspirin } & $3 \mathrm{mM}$ & 1.83 & 26.8 \\
\hline & $6 \mathrm{mM}$ & 1.0 & 60 \\
\hline & $9 \mathrm{mM}$ & 1.0 & 60 \\
\hline & $12 \mathrm{mM}$ & 0.833 & 66.68 \\
\hline \multirow{4}{*}{ Ibuprofen } & $3 \mathrm{mM}$ & 1.5 & 40 \\
\hline & $6 \mathrm{mM}$ & 1.08 & 56.8 \\
\hline & $9 \mathrm{mM}$ & 0.58 & 76.8 \\
\hline & $12 \mathrm{mM}$ & 0.5 & 80 \\
\hline \multirow{4}{*}{ Indometacine } & $3 \mathrm{mM}$ & 1.66 & 33.6 \\
\hline & $6 \mathrm{mM}$ & 0.83 & 66.8 \\
\hline & $9 \mathrm{mM}$ & 0.58 & 76.8 \\
\hline & $12 \mathrm{mM}$ & 0.58 & 76.8 \\
\hline \multirow{4}{*}{$\begin{array}{l}\text { Oil of the } \\
\text { Soapwort }\end{array}$} & $102 \mu \mathrm{g} \mathrm{ml}^{-1}$ & 1.5 & 40 \\
\hline & $204 \mu \mathrm{g} \mathrm{ml}^{-1}$ & 0.83 & 66.8 \\
\hline & $306 \mu \mathrm{g} \mathrm{ml}^{-1}$ & 0.5 & 80 \\
\hline & $408 \mu \mathrm{g} \mathrm{ml}^{-1}$ & 0.91 & 63.6 \\
\hline
\end{tabular}

Note: Standard activity (activity without any addition) of COX-2 enzyme is $2.5 \times 10^{-3} \mathrm{U} / \mathrm{ml}$.

\section{Discussion:}

The most important reasons behind our choice of rheumatoid 
arthritis in the current study is our belief that the natural products of Soapwort include substances that have an ability to address the most important problems causing the continuation of this disease. Based on that, the current study aims to isolate and diagnose the natural products found in Soapwort and then study its effect on the activity of (COX-2) enzyme which is one of the most important enzymes that is responsible for the inflammation as in rheumatoid arthritis.

The pure enzyme obtained shows a single band when analyzed by acrylamide electrophoresis in the presence of $0.1 \%$ sodium dodecyl sulfate. The relative distance of the COX-2 is $(4.85 \mathrm{~cm})$ and it is clear that the enzyme has a molecular weight equal to $(71.6 \mathrm{kDa})$ when using the standard curve shown in Figure 5. Additionally, it elutes as a single peak (peak $\mathrm{C}$ in Figure 2) from the ion exchange technique column. These results are close to the findings of the previous study [24] which shows that the value of molecular weight of the enzyme is $(72 \mathrm{kDa})$ and that the enzyme catalyzes both reactions of cycolooxygenase and the prostaglandin $\mathrm{G}(\mathrm{PGG}) \rightarrow$ prostaglandin $\mathrm{H}(\mathrm{PGH})$ peroxidase at the same time and this is an additional evidence to support that COX-2 gives a single band when analyzed by acrylamide electrophoresis.

The current study shows that the oil of the Soapwort has ability to inhibit COX-2 activity better than ability of anti-inflammatory drugs shown in Table 4 . The mechanism by which oil inhibits the activity of COX2 enzyme is not clear but the presence of fatty acids in this oil may be a cause of this inhibition where the study of Yuan, et al [34] shows that fatty acids binds within the COX-2 site of one monomer of the dimer and inhibit the binding and oxygenation of substrate in the COX site of the other monomer. Thus, the effect is likely to negative allosteric effect. Aspirin is an irreversible inhibitor of the COX-2 that acts as an acetylating agent where an acetyl group is covalently attached to a serine residue in the active site of the COX-2 [35]. Ibuprofen and Indometacin are both competitive reversible inhibitors but each belongs to two different categories. The kinetic difference between category 1 and 2 is the speed and efficiency by which they gain access through the narrow constriction in the COX-2 channel created by Arg120, Tyr355 and Glu524 [36].

The present study also shows that flavonoids and Saponin extracts have no impact on the effectiveness of COX-2 enzyme in an in vitro model as shown in Figure $8(b, c)$. This means that the mechanical working through these materials to suppress inflammation is not centered on the enzyme itself but may be through effective influence on the factors that induce the expression of this enzyme. It is noted from the different studies that flavonoids acting as antioxidants in addition to being a blocker inflammation [37, 38] as well as Saponin possible work as a disincentive for the genes responsible for the secretion of the COX-2 enzyme [39]. All these are positive points gathered together in Soapwort plant and give a clear indication of the importance of this plant in the medical field especially with regard to its role as anti-inflammatory material that may plays important role in the treatment of rheumatoid arthritis by preventing the oxidative stress, reducing prostaglandins and by inhibiting the COX-2. Finally the current study needs to support its findings by verifying the effect of Soapwort extracts at the level of antioxidants, prostaglandins and at the effectiveness 
of the COX-2 enzyme. This is done through a study on experimental animals that will be our goal in the next part of the current study.

\section{Conclusions}

The qualities of natural products that have been diagnosed in the Soapwort extracts give a clear indication of the importance of this plant in the medical field especially with regard to its role as antiinflammatory materials (hence important treatment for rheumatoid arthritis) by inhibition of a cyclooxygenase- 2 .

\section{References:}

[1] Rouzer, C. A. and Marnett, L. J. 2009. Cyclooxygenases: structural and functional insights. J. Lipid Res; 23: 29-34.

[2] Hedin, L.; Rask, K.; Zhu, Y.; Wickman, A.; Wang, W.; Brevinge, H.; Thorn, M.; Ponte'n, F. and Sundfeldt, K. 2013. Role of prostaglandins in colorectal tumorigenesis: Localization and expression of COX-1, COX-2, microsomal Prostaglandin E Synthase-1 and the EP2 receptor, Avicenna; 5: 1-12.

[3] Murray, R. K.; Bender, A. B.; Botham, K.; Kennelly, P.; Rodwell, V. W. and Weil P. A. 2009. Harper's Illustrated Biochemistry, $28^{\text {th }}$ ed., The Mcgraw-Hill Companies,China. $p$ 192.

[4] St-Louis, I.; Singh, M.; Brasseur, K.; Leblanc, V.; Parent, S. and Asselin, E. 2010. Expression of COX-1 and COX-2 in the endometrium of cyclic, pregnant and in a model of pseudopregnant rats and their regulation by sex steroids. $R B \& E$; 8(1): 103-115.

[5] Zhang, W. Y.; Yang, X. N.; Jin, D. Z. and Zhu, X. Z. 2004. Expression and enzyme activity determination of human cyclooxygenase- 1 and -2 in a baculovirus-insect cell system. Acta Pharmacol Sin; 25 (8): 10001006.

[6] Nochi, H.; Tomura, H.; Tobo, M.; Tanaka, N. and Sato, K. 2008. Stimulatory Role of Lysophosphatidic Acid in Cyclooxygenase-2 Induction by Synovial Fluid of Patients with Rheumatoid Arthritis in Fibroblast-Like Synovial Cells. $J$ Immunol; 181:5111-5119.

[7] Schlachetzki, J. C.; Fiebich, B. L.; Haake, E.; de Oliveira, A. C.; Candelario-Jalil, E.; Heneka, M. and Hüll, M. 2010. Norepinephrine enhances the LPSinduced expression of COX-2 and secretion of PGE2 in primary rat microglia, $J$ Neuroinflammation; 11: 2-7.

[8] Yoon, W. J.; Ham, Y. M.; Kim, S. S.; Yoo, B. S.; Moon, J. Y.; Baik, J.S.; Lee, N.H. and Hyun, C. 2009. Suppression of pro-inflammatory cytokines, iNOS, and COX-2 expression by brown algae Sargassum micracanthum in RAW 264.7 macrophages EurAsia $J$ BioSci. 3: 130-143.

[9] Hai, L.; Kawarabayashi, Y.; Imai, Y.; Hond, A. and Inoue, R. 2011. Counteracting effect of TRPC1associated $\mathrm{Ca} 2+$ influx on TNF- $\alpha-$ induced COX-2-dependent prostaglandin E2 production in human colonic myofibroblasts, Am. J. Physiol. Gastrointest. Liver Physiol; 301: 356-367.

[10] Dönmez, A. A. 2009. Saponaria suffruticosa (Caryophyllaceae): An enigmatic; species from southwest Asia on border of Turkey and Iraq, Hacettepe J Biol; 37(3): 18187.

[11] Coombes, A. J. 2012. The A to $\mathrm{Z}$ of Plant Names. USA: Timber Press. p. 265. 
[12] Arslan, I. and Çelik, A. 2013. Saponin rich fractions(SRFs) from Soapwort show antioxidant and hemolytic activity, APCBEE Procedia; 7: $103-108$.

[13] Lemmel, M. J. 2006. Tipos y preparados antialopécicos, OFFARM; 29 (9): 52-60.

[14] Nathan, C. 2002. Points of controls in inflammation. Nature; 420: 846-885.

[15] Ali, E. A. 2010. Evaluation of Serum Soluble Interleukin -2 Receptor level in Diagnosis of Rheumatoid Arthritis. JKU; 8(1): 269-275.

[16] Moscoso, F.; Deive, F. J.; Esperança, J. S. and Rodríguez, A. 2013. Pesticide Removal from Aqueous Solutions by Adding Salting Out Agents, Int. J. Mol. Sci.; 14: 20954-20965.

[17] Miltko, R.; Bełżecki, G.; Kasperowicz, A. and Michałowski, T. 2010. Isolation and Purification of Chitinolytic Enzymes of Rumen Ciliates Eudiplodinium maggii. PCACD; 15:189-196.

[18] Burgess, R. R. and Dutscher, M. P. 2013. Guid to protein (purification and characterization), Method in Enzymology., (463): 320.

[19] Clark, M. A.; Finkel, R.; Rey, J. A. and Whalen, K. 2012. Pharmacology. 5th ed., Lippincott Williams and Wilkins, a Wolters Kluwer business, Philadelphia.; P..526, 530, 541.

[20] Nireesha, G. R.; Divya, L.; Sowmya, C. and Venkateshan, N. M. 2013. Niranjan Babu and V. Lavakumar. Lyophilization/ Freeze Drying - An Review, IJNTINP; 3(4): 87-98.

[21] Mikkelsen, S. R. 2004. Bioanalytical Chemistry. John wiley and sons Inc. Hoboken, New
Jersey in the United states of America. P.26.

[22] Walker, J. M. 2002. The Protein Protocols Handbook, 2nd Edition Humana Press Inc., Totowa, NJ; Part II, p 61.

[23] Nelson, D. L. and Cox M. 2005. Lehninger Principles of Biochemistry. 4th ed., USA.P:92.

[24] Van der Ouderaa, F. J.; Buytenhek, M.; Nugteren, D. H. and van Dorp, D. A. Biochim. Biophys. Acta 487, 315. 1977. cited by Lands, W.E. and Smith, W.L. Prostoglandins and Arachidonate Metabolites. Methods in Enzymology., 1982; 86: 62.

[25] Lowry, O.H., Rosbrough, N.J., Farr, A.L. and Randall, R.J. 1951. Protein measurement with the Folin phenol reagent, J. Biol. Chem.; 193: 265.

[26] Zekovie, P.Z., Lepojevie, Z.D. and Mujie, I.O. 2009. Laurel Extracts Obtained by Steam Distillation, Supercritical Fluid and Solvent Extraction. J. Natu. Products, 2: 104-109.

[27] Al-Saidy, H.A., Mwaffek, Y. and Abdala, N. 2014. Using of Plant Extracts for Cinnamon, Syzygium and Thyme to Degradation of Aflatoxin B1. JNSR; 4(17): 1-7.

[28] Al-Obiady, M.A. 2006. Lipid components and fatty-acid composition of human serum in diabetic patients. Ph.D thesis, College of Education, University of Mosul, P: 44, 45.

[29] Kato, H.; Li, W.; Koike, M. and Koike, K. 2010. Phenolic glycosides from Agrimonia pilosa. J. phytochem; 71 (16):1925-1929.

[30] Krishna, S. and Renu, S. 2013. Isolation and identification of flavonoids from cyperus protundus lin in vivo and in vitro. JDDT; 3(2):109-113. 
[31] Ceyhun Sezgin, A. E. and Artk, N. 2010. Determination of Saponin Content in Turkish Tahini Halvah by Using HPLC. $A d v . J$. Food Sci. Technol; 2(2): 109-115.

[32] Al-Dawah, N. K. and Ibrahim, S.L. 2013. Phytochemical characteristics of Date Palm (Phoenix dactylifera L.) leaves extracts. Kufa j. vet. Sci.; 4(1): 9095.

[33] Deeb, R. S.; Hao, G.; Gross, S. S., Laine; M., Qiu, J. H.; Resnick, B.; Barbar, E. J.; Hajjar, D. P. and Upmacis, R. K. 2006. Heme catalyzes tyrosine 385 nitration and inactivation of prostaglandin H2 synthase- 1 by peroxynitrite. $J$. Lipid Res; 47: 898 -911.

[34] Yuan, C.; Sidhu, R. S.; Kuklev, D. V.; Kado, Y.; Wada, M.; Song, I., and Smith, W. L. 2009. Cyclooxygenase Allosterism, Fatty Acid-mediated Cross-talk between Monomers of Cyclooxygenase Homodimers. $J$ Biol Chem; 284(15):10046-10055.

[35] Tóth, L.; Muszbek, L. and Komáromi, I. 2013. Mechanism of the irreversible inhibition of human cyclooxygenase-1 by aspirin as predicted by QM/MM calculations. J Mol Graph Model; 40: 99-109.

[36] Selinsky, B. S.; Gupta, K.; Sharkey, C. T. and Loll, P. J. 2001. Structure analysis of NSAID binding by prostaglandin $\mathrm{H} 2$ synthase: time dependent and time-independent inhibitors elicit identical enzyme conformations, Biochemistry; 40: 5172-5180.

[37] Ivanisova, E.; Tokar, M.; Mocko, K.; Bojnanska, T.; Marecek, J. and Mendelova, A. 2013. Antioxidant activity of selected plant products. JMBFS; 2 (1): 1692-1703.

[38] Angst, E., Park, J.L., Moro, A. and $\mathrm{Lu}, \mathrm{Q} . Y$. 2013. The flavonoid quercetin inhibits pancreatic cancer growth invitro and in vivo, Pancreas; 42(2): 223-229.

[39] Song, J.; Yeo, S.; Hong, E.; Lee, B.; Kim, J.; Jeong, H.; Kwon, Y.; Kim, H.; Lee, S.; Park, H. and Ko, H. 2014. Antiviral Activity of Hederasaponin B from Hedera helix against Enterovirus 71 Subgenotypes C3 and C4a. Biomol Ther; 22 (1): 41-46. 


\section{عزل وتتقية انزيم السايكلوكسي جينيز-2 من دم مريض يعاني التهاب المفاصل}

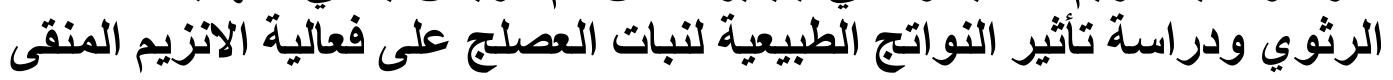

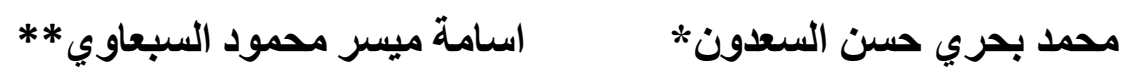

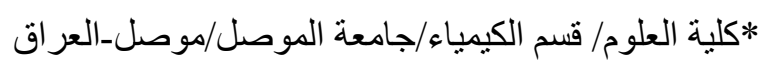

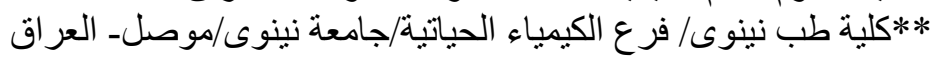

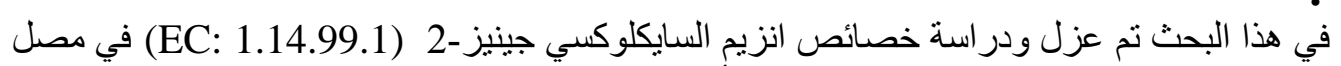

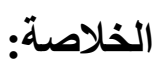

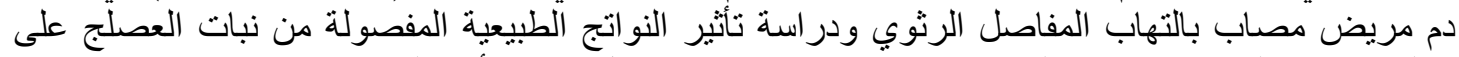

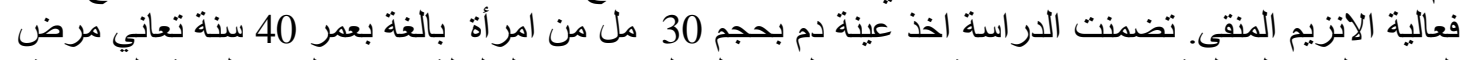

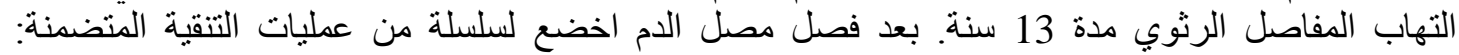

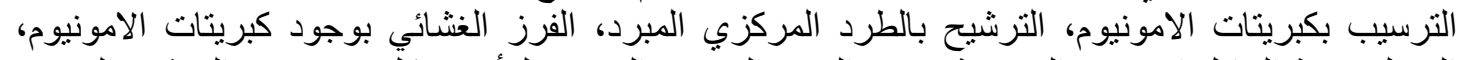

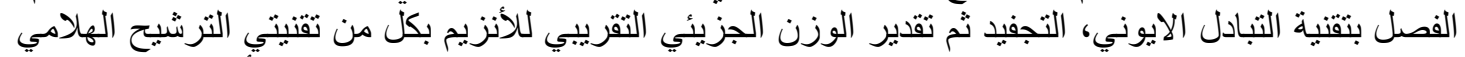

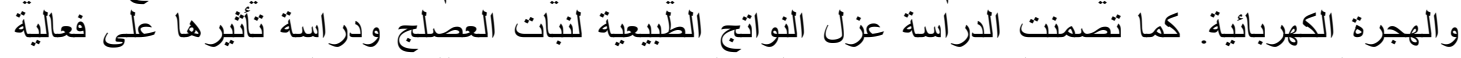

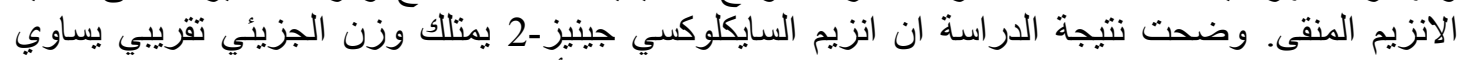

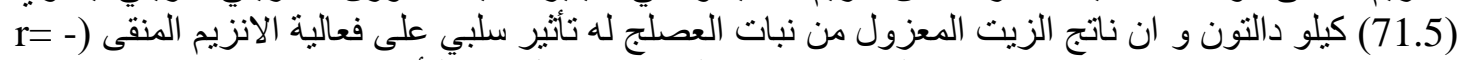

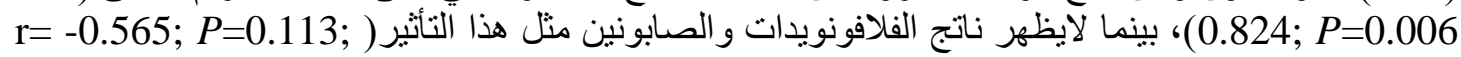
(r= -0.634; $P=0.067$

الكلمات المفتاحية: السايكلو كسي جينيز -2، التهاب المفاصل الرثوي،التنقية ، نبات العصلج. 